Buca Eğitim Fakültesi Dergisi, 2021, Say1 51, s. 76-96

Araştırma Makalesi
The Journal of Buca Faculty of

Education, 2021, Issue 51, p.76-96

Original Research

\title{
Tahmin Et-Gözle-Açıkla (TGA) Materyalleri ve Lise Öğrencilerinin Kimya Dersine Yönelik Tutumları*
}

\section{The Predict-Observe-Explain (POE) Activities and High School Students' Attitudes towards Chemistry Course}

\author{
Sibel ÖZSOY', Fatma ALKAN², Ayșem Seda YÜCEL ${ }^{3}$
}

\begin{abstract}
${ }^{1}$ Ögrretmen,Eğitim Bilimleri Enstitüsü, Hacettepe Üniversitesi, Türkiye, s.sibeltekin@gmail.com, (https://orcid.org/0000-0001-5829-2737)

${ }^{2}$ Sorumlu Yazar, Doç. Dr., Matematik ve Fen Bilimleri Eğitimi Bölümü, Eğitim Fakültesi, Hacettepe Üniversitesi, Türkiye, alkanf@hacettepe.edu.tr, (https://orcid.org/0000-0003-2784$875 X)$

${ }^{3}$ Prof. Dr., Matematik ve Fen Bilimleri Ĕgitimi Bölümü, Eğitim Fakültesi, Hacettepe Üniversitesi, Türkiye,aseda@hacettepe.edu.tr, (https://orcid.org/0000-0001-7805-5990)
\end{abstract}

Geliş Tarihi: 24.07 .2020

Kabul Tarihi: 04.03.2021

Öz

$\mathrm{Bu}$ araştırmanın amacı tahmin et-gözle-açıkla (TGA) yöntemine göre hazırlanmış materyaller ile öğretimin lise 10. sınıf öğrencilerinin kimya dersine yönelik tutumları üzerine etkisini incelemektir. Araştırmada öntest-sontest kontrol gruplu yarı deneysel desen kullanılmıştır. Araştırmanın örneklem grubunu Ankara ilinde iki farklı Anadolu Lisesinde 10. sınıfta öğrenim gören 100 öğrenciden oluşturmaktadır. Deney gruplarında dersler TGA destekli materyaller ile uygulanırken, kontrol gruplarında ise geleneksel yöntem ile gerçekleştirilmiş̧ir. Veri toplama aracı olarak Kimya Dersine Yönelik Tutum Ölçeği kullanılmıştır. Analiz sonucunda göre ölçeğin tüm alt boyutlarında deney ve kontrol gruplarının son test puanları arasında anlamlı farklılık vardır. Buna göre deney 1 ve 2 gruplarının kimya dersine yönelik tutum ölçeğinin tüm alt boyutlarındaki ortalamaları kontrol 1 ve 2 gruplarınınkinden daha yüksektir ve ortalamalar arasındaki fark istatistiksel olarak anlamlıdır.

Anahtar Kelimeler: Tahmin et-gözle-açıla (TGA) materyalleri, kimya dersi tutum, lise öğrencileri.

\begin{abstract}
The purpose of this research is to investigate the effects of teaching of chemistry taught using materials supported by the predict-observe-explain (POE) on students' attitudes towards chemistry course. In the research, quasi-experimental design with pretest-posttest control group was used. The sample group of the research consists of approximately 100 students studying in 4 different 10th grades in two different Anatolian High Schools in Ankara in the 2016-2017 academic year. The lessons were carried out with POE supported activities in the experimental groups; however, traditional method was carried out in the control groups. Attitude towards chemistry course scale was used as the data collection tool. According to the analysis result, there was a statistically significant difference between experiment and control groups in all sub-dimensions of the scale posttest scores. The averages of experiment 1 and 2 groups in all subdimensions of the scale are higher than the control 1 and 2 groups, and the difference between the averages is statistically significant.
\end{abstract}

\footnotetext{
${ }^{*}$ Bu çalışma üçüncü yazar danışmanlığı, ikinci yazar yardımcı danışmanlığında yürütülen, birinci yazara ait yüksek lisans tezinin bir bölümünden hazırlanmıştır.
} 
Keywords: Predict-observe-explain activities (POE), attitudes towards chemistry course, high school students.

\section{GİRIȘ}

Günümüzde yenilikçi bir eğitim-öğretim sistemine kavuşmak için yapılması gerekenler büyük çaplı bir değişimin öncüsü durumundadır. Gelişmiş ülkelerde uygulanan modeller, yaklaşımlar, yöntemler gelişmekte olan birçok ülke tarafinda da rol model olarak alınmakta, benzer uygulamalar kullanılmaya çalışılmaktadır. Geçmişten gelen geleneksel eğitim-öğretim uygulamalarının günümüz bireylerinin öğrenme durumları üzerinde yeterli ve kalıcı bir etki yaratmadığı birçok araştırmayla kanıtlanmıştır (von Glasersfeld, 1995; Tan, 2008). Yeni nesil çok boyutlu düşünme becerisine sahip, hem zihnen hem de bedenen aktif olmaktan haz duyan, üst bilişsel becerileri yüksek, her an her noktadan sınırsız bilgi erişimine açık bir sistem ağı içerisinde yaşayan bireylerden oluşmaktadır. Geleneksel eğitim-öğretim modelleri ve yeni jenerasyon birlikte düşünüldüğünde ikili arasındaki büyük tezatlık çarpıcı bir şekilde sorun oluşturmaktadır. Bu sebeple, okullarda öğrenme ortamları; geleneksel, tek düze, sıkıc1, öğreten otoritesindeki anlatım yöntemlerinden sıyrılıp, uygulamalı, öğrenci merkezli, öğrencilerin aktif katılımla fikirlerini özgürce açıklayabilecekleri dinamik sınıf ortamlarına dönüştürülmelidir (Bednar, Cunningham, Duffy ve Perry, 1992; Özdemir, 2006; Akkaya, 2010; Altınok, 2017). Öğrenme ortamlarının bu şekilde kurgulanması, anlamlı ve kalıcı öğrenmeyi sağladığ gibi, öğrencinin bilgiyi yaşama transfer becerilerini geliştirdiği, bilgileri disiplinler arası düşünerek zihninde kurguladığı, öğrenmekten sıkılmadığı, etkin rol almaktan korkmadığı bir öğrenme penceresi de oluşturmaktadır. Son yıllarda yapılan çalışmalarda fen bilimlerinin diğer alanlarında olduğu gibi kimya alanı çerçevesinde oluşturulan öğretim programlarının öğretmenler için en önemli yaptırımının, öğrenme ve öğretmeyi geliştirmek amacıyla öğrencilerin ön bilgilerinin belirlenmesi gerekliliğidir. Bu şekilde öğrencilerin sahip oldukları ve öğrenme süreçlerini etkileyecek alternatif kavramların tespit edilmesi de sağlanmış olacaktır. Fen eğitimi ile ilgili yapılan birçok araştırma da öğrencilerin kimya konularıyla ilgili olarak birçok alternatif kavrama sahip olmaları nedeniyle derslerde başarısızlık yaşadıkları ve kimya dersine yönelik olumsuz yaşantılar geliştirdikleri saptanmıştır (Palmer, 1999; Osborne ve Wittrock, 1983). Öğrenciler henüz ortaokul düzeyinde fen bilimlerini öğrenmekte ve temel becerileri edinmektedirler. O yaşlarda fen bilimlerine ilgi oluşmaya başlamakta ve bu ilginin devamlılığının sağlanması önem kazanmaktadır (Sheldrake ve Mujtaba, 2020). Günlük hayatımızdaki olayların birçoğu kimya ile ilişkilidir (Özmen, 2004; Özden, 2007). Kimya ile günlük hayatımızda karşılaştığımız olaylar arasında bağlantıların kurulması kimya eğitiminde oldukça önemlidir (Altundağ Koçak, 2018). Öğrenciler de kimyanın hayatımızın çeşitli alanlarıyla ilişkili olduğunun farkındadırlar. Hatta kimya bilgilerini günlük yaşamlarıyla ilişkilendiremediklerinde öğrenme süreçlerinde sorunların ortaya çıkacağının da bilincindedirler (Rüschenpöhler ve Markic, 2020). Kimya, öğrenciler tarafından zor bir bilim olarak anılmakta ve bu alanda eğitim alıp kariyer yapmanın güç olduğu düşünülmektedir (Mujtaba, Sheldrake ve Reiss, 2020). Öğrenciler kimyanın zorlayıcı olmasını bazı konularının soyut ve anlaşılmasının zor olmasına bağlamaktadır (Rüschenpöhler ve Markic, 2020). Öğrencilerin, sahip oldukları alternatif kavramları ve olumsuz tutumları önemli ölçüde ortadan kaldırarak öğretilen bilgilerin doğru bilimsel alt yapıyı oluşturacak biçimde kalıcı olabilmesi için anlamlı öğrenmenin gerçekleşmesi gerekmektedir. Günümüzde anlamlı öğrenmenin gerçekleşebilmesi için başvurulacak uygun öğretim yaklaşımlarından yapılandırmacı yaklaşım destekli etkinliklerin uygulanması büyük önem taşımaktadır. Yapılandırmacı yaklaşım temelli yöntemlerden biri olan Tahmin et-Gözle-Açıkla (TGA)'nın kullanılmasının söz konusu hedeflere ulaşılması sürecine katkı sağlayacağı düşünülmektedir.

Tahmin Et-Gözle-Açıla (TGA) (Predict-Observation-Explain POE) stratejisi ilk olarak White ve Gunstone'nın (1992) yaptığı çalışmada açıklanmaktadır. TGA'da öğrenciler bir durum ile karşılaşırlar, ardından bu durumun sonuçları ile ilgili tahminde (predict) bulunurlar ve daha 
sonra, durumla ilgili gözlem (observe) yaparlar. En son aşamada tahminler ile gözlemleri karşılaştırarak açıklama (explain) yaparlar. Daha detaylı bir şekilde ifade edilecek olursa, TGA stratejisinde araştırılacak konu öğrencinin ilgisini çekecek biçimde bir durum haline getirilerek sorular sorulur, öğrenciler araştırılacak olayların sebepleri ile beraber ve sonuçları hakkında tahminde bulunurlar. Konu veya soru ile ilgili gözlemler yaparlar. Gözlemleri 1şı̆̆ında başlangıçtaki tahminleri ile kıyaslamalar yaparlar ve tahminleri ile gözlemleri arasındaki farklılıkları yorumlarlar ve açıkla bölümündeki soruları cevaplarlar. TGA sınıf ortamında öğrencinin aktif katılımını üst düzeyde tutan, öğrencilerin olayları sonuçları ile birlikte ifade edebildikleri en önemli yöntemlerden biridir. Öğrenciler kitap, dergi, gibi kaynaklardaki ilgileri zihinlerinde anlamlandırmadan sadece ezberlemekten ziyade, verilen konuya sahip oldukları bilgi seviyesi kadar açıklama getirmiş olmakta ve bu şekilde mevcut alternatif kavramlarının yerine doğru bilimsel alt yapıyı oluşturma süreçlerinde başarılı olmaktadırlar.

\subsection{Araştırmanın Amacı ve Önemi}

Fen bilimlerinin ana bileşenlerinden olan kimya derslerinin öğrenciler tarafından bazı konularının soyut ve anlaşılması zor olduğu için çalışılmayan, anlaşılabilirliği güç olduğu için sevilmeyen ve sonuç olarak da başarı oranının düşük bir ders olduğu bilinmektedir. Kimya ile ilgili bu olumsuzlukların üstesinden gelinebilmesi için kimyanın daha anlamlı ve ilginç hale getirilmesi gerekir. Bunun için kimya derslerinde daha çok laboratuvar etkinliği ve pratik çalışmaların yapılması üzerinde önemle durulmaktadır (Broman, Ekborg ve Johnels, 2011). Öğretmenler malzeme eksikliği (Cheung, 2008; Ramnarain, 2016), araç-gereç kullanım bilgi yetersizliği (Aydoğdu, 1999), ders saati ve müfredatın yetişmemesi (Cheung, 2011) gibi nedenlerden dolayı kimya derslerinde laboratuvar etkinliklerden uzaklaşmaktadır. Sonuç olarak öğretmenler geleneksel eğitim anlayışından uzaklaşamamakta ve öğrenci ile etkileşimli bir öğrenme ortamı oluşturamamaktadır. Kimya derslerinde pratik çalışmalara yönelik etkinlikler kimyanın öğrenciler tarafindan anlaşılabilir ve uygulanabilir olacağını kavramalarını sağlayacaktır (Mujtaba, Sheldrake ve Reiss, 2020). TGA yöntemi bir taraftan öğrencinin derse aktif katılımını sağlayacak, diğer taraftan ise bilginin öğrenci zihninde yapılandırılmasına yardımcı olacak bir yöntem olarak dikkati çekmektedir. Bu araştırmada, TGA (tahmin et-gözleaçıkla) ile desteklenmiş materyaller kullanılarak işlenen kimya derslerinin öğrencilerin kimya dersine yönelik tutumları üzerine etkisi incelenmiştir. Literatür incelendiğinde TGA yönteminin öğrenmede başarı (Yaman ve Ayas 2015; Venida ve Sigua 2020), kavramsal anlama (Samsudin, Suhandi, Rusdiana, Kaniawati ve Coştu, 2016), problem çözme (Fitriani, Zubaidah, Susilove ve Al Muhdhar, 2019) ve bilişötesi farkındalık (Karadeniz, Koçak Altundağ ve Yücel, 2020) üzerine etkisini inceleyen çalışmalar olduğu ancak tutum üzerine etkisini inceleyen yeterli çalışmanın olmayışı fark edilmektedir. Bu araştırmanın lise düzeyinde kimya dersinin TGA yöntemine göre hazırlanmış materyaller ile öğretiminin öğrencilerin kimya dersine yönelik tutumları üzerine olumlu etkisi yönünde alana katkı sağlayacağı düşünülmektedir.

\section{YÖNTEM}

Araştırmada öntest-sontest kontrol gruplu yarı deneysel desen kullanılmıştır (Karasar, 2003). Endüstri ve Canlılarda Enerji ünitesinin Hidrokarbonlar konusu TGA yöntemine göre hazırlanmış materyaller ile öğretiminin lise 10. sınıf öğrencilerinin kimya dersine yönelik tutumları üzerine etkisi araştırılmıştır.

\section{1. Örneklem}

Araştırmanın örneklem grubu Ankara ilinde iki farklı Anadolu Lisesinde 10. sınıfta öğrenim gören 100 öğrenciden oluşmaktadır. Deney grubunda 50, kontrol grubunda 50 öğrenci bulunmaktadır. Liselerde sınıflardaki ögrenci sayısı dikkate alınarak her bir okuldan bir deney ve bir kontrol grubu belirlenmiştir. Buna göre sayıların dağılımı deney grubu 1'de 25 öğrenci, 
kontrol grubu 1'de 25 öğrenci, deney grubu 2'de 25 öğrenci ve kontrol grubu 2'de 25 öğrenci şeklindedir. Araştırma 2016-2017 öğretim yılında gerçekleştirilmiştir.

\section{2. Öğretim Süreci}

Deney gruplarında önce hidrokarbonlar konusu ve hidrokarbonların elde ediliş genel bilgiler kısaca verilmiştir. 2016-2017 yılları MEB 10. sınıf Endüstri ve Canlılarda Enerji ünitesi içeriğindeki kazanımlar dikkate alınarak TGA'nın Tahmin et-Gözle-Açıkla basamakları baz alınarak hazırlanan materyaller kullanılmıştır. Tahmin et basamağında öğrenciler verilen durum hakkında tahminde bulunurlar. Gözle basamağında öğrenciler hidrokarbonlar konusuna uygun tasarlanan deneyleri yapar, videoları izlerler. Açıkla basamağında ise öğrenciler deney ve video gözlemlerinden elde ettikleri sonuçlar doğrultusunda, kıyaslamalar yaparak çeşitli soruları cevaplarlar. Şekil 1'de öğrencilere uygulanan materyallerden bir örneğin "Tahmin et", "Gözle" ve "Açıkla" bölümlerinden bir kesit verilmiştir. Tahmin et-gözle-açıkla yönteminin ikinci bölümünde yapılandırmacı temellere dayalı kimya deneyleri yapılmıştır.

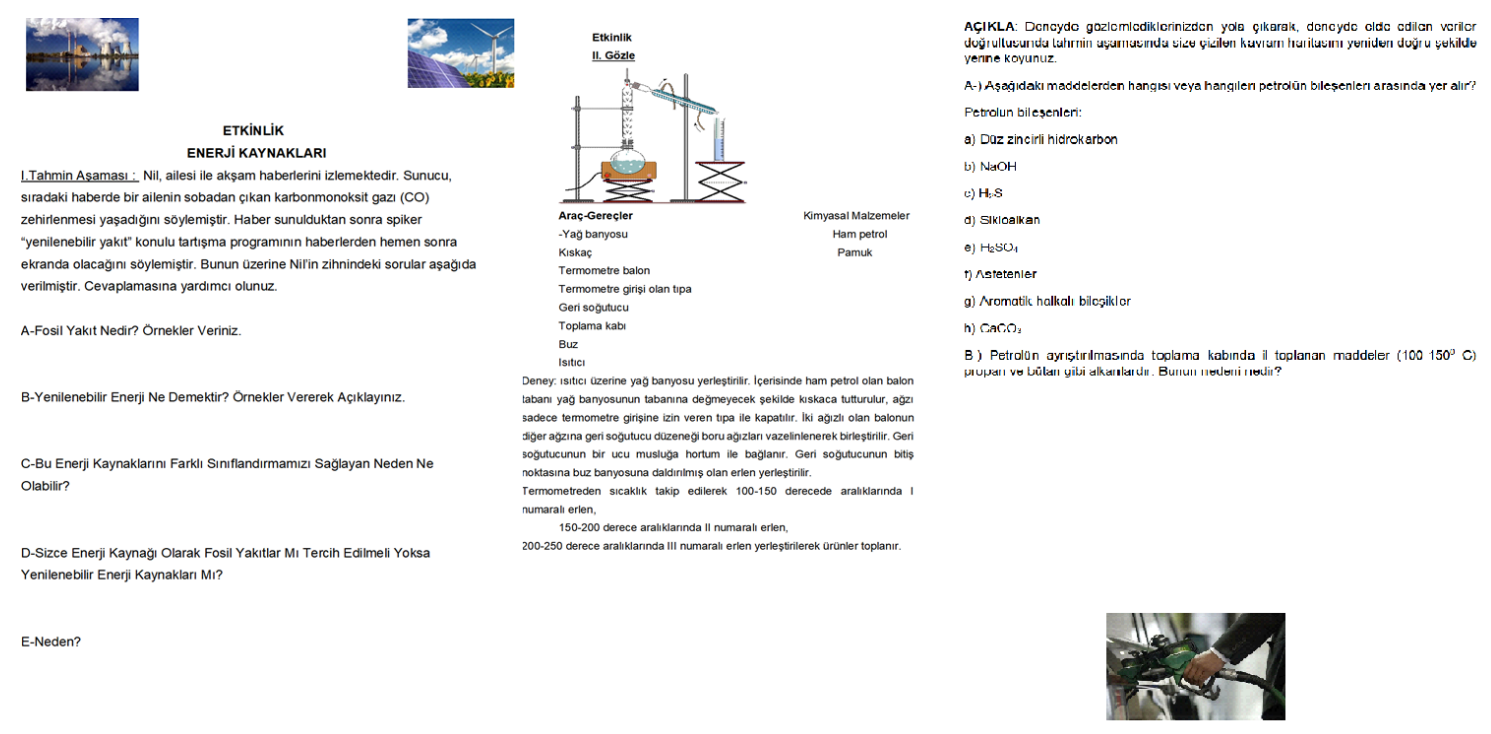
Kesiti

Şekil 1. Öğrencilere Uygulanan Materyallerden Bir Örneğin "Tahmin Et, Gözle ve Açıkla”

Kontrol gruplarında Endüstri ve Canlılarda Enerji ünitesinin hidrokarbonlar konusu geleneksel yönteme bağlı kalınarak işlenmiştir. Ancak geleneksel yöntem, soru-cevap tekniği ve sunumlar ile desteklenmiş̧ir. Uygulama okullarından bir kontrol grubunda ders öğretmen tarafından yürütülürken, diğer okulda ders araştırmacı tarafindan yürütülmüştür. Dersin işlenişinde önceden hazırlanan ders planları takip edilmiştir. Kimya ders kitabında hidrokarbonlardan elde edilen ürünlerin hayatımızda nerelerde bulunduğu ve bu ürünlerin nerelerde kullanıldığı ile ilgili bilgiler bulunmaktadır. Bu nedenle, ders öğretmeni öğrencilere her bir hidrokarbon ürününün özelliklerinden bahsettikten sonra, o hidrokarbonun günlük yaşamdaki kullanım alanı ile ilgili de bilgilendirme yapılmıştır. Öğretmen tarafindan öğrencilere sorular sormuştur. Verilen doğru cevaplar öğretmen tarafından pekiştirilirken, yanlış cevaplar düzeltilmiş ve ders süresince öğrenciler defterlerine notlar almışlardır. Uygulamalar deney ve kontrol grubunda on ders saati süresinde tamamlanmıştır.

\subsection{Veri Toplama Araçları}

$\mathrm{Bu}$ araştırmada, yapılandırmacı yaklaşıma dayanan tahmin et-gözle-açıkla yöntemi ile desteklemiş materyallerin, öğrencilerin kimya dersine yönelik tutumlarına etkisi incelenmek üzere Kan ve Akbaş'ın (2005) geliştirdiği Kimya Dersine Yönelik Tutum Ölçeği kullanılmıştır. 
Ölçek, 5'li Likert tipinde 22 maddeden oluşmaktadır. Ölçeğin üç alt boyutu vardır, bunlar kimya dersine dönük olumsuz duygu, kimya dersine dönük olumlu duygu ve kimya dersine dönük faaliyettir. Ölçeğin Cronbach Alpha güvenirlik katsayısı 0.92'dir. Ölçeğin kimya dersine dönük olumsuz duygu alt boyutunun güvenirliği 0.87 , kimya dersine dönük olumlu duygu alt boyutunun 0.87 ve kimya dersine dönük faaliyet alt boyutunun ise 0.78 'dir.

\subsection{Verilerin Analizi}

Araştırmada tutum ölçeğinden elde edilen verilerin analizinde SPSS 23.0 istatistik programı kullanılmıştır. Verilerin analizinde öncelikli olarak tanımlayıcı istatistik yapılmıştır. Lise ögrencilerinin kimya dersine yönelik tutumlarının alt boyutlarındaki ortalamaları belirlenmiştir. Deney ve kontrol gruplarının uygulama öncesi kimya dersine yönelik tutum durumları belirlenmiş ve arada bir fark olup olmadığı kıyaslanmıştır. Kimya dersine yönelik tutum ölçeği alt boyutlarından elde dilen sontest puanları Çok Değişkenli Varyans Analizi (MANOVA) ile incelenmiştir.

\section{BULGULAR}

Lise öğrencilerinin Deney 1, Deney 2, Kontrol 1 ve Kontrol 2 grubunda olmalarının kimya dersine yönelik tutum ölçeğinin kimya dersine dönük olumsuz duygu, kimya dersine dönük olumlu duygu ve kimya dersine dönük faaliyet alt boyutları üzerine etkisini değerlendirmek için iki yönlü Çok Değiş̧kenli Varyans Analizi (two-way Multivariate Analysis of Variance, MANOVA) yapılmıştır. İlk olarak verilerin MANOVA'nın sayıltılarını karşılayıp karşılamadığı incelenmiştir. Bu amaçla tek değişkenli ve çok değişkenli normal dağılım, varyans-kovaryans matrislerinin homojenliği ve çoklu ortak doğrusallık incelenmiştir.

\subsection{Normallik Varsayımı}

Bir değişkenden elde edilen verilerin normallik varsayımı betimsel, grafiksel ve istatistiksel yöntemlerle incelenmektedir (Thode, 2002; Sharma, 1996). Kimya dersine yönelik tutum ölçeğinden elde edilen verilerin tek değişkenli ve çok değişkenli normallik varsayımını karşılayıp karşılamadığ 1 betimsel, grafiksel ve istatistiksel olarak incelenmiştir. Betimsel yöntemler olarak aritmetik ortalama, standart sapma, çarpıklık ve basıklık katsayıları gibi istatistikler üzerinden inceleme yapılır (Kirk, 2008). Sonuçlar Tablo 1'de verilmektedir.

Tablo 1. Kimya Dersine Yönelik Tutum Ön-test Ölçümleri Tüm Gruplara İlişkin Normallik Varsayımı Betimsel Yöntemler

\begin{tabular}{|c|c|c|c|c|c|c|c|c|}
\hline & & $\overline{\mathrm{x}}$ & Ss & $\begin{array}{l}5 \% \\
\text { Budanmış } \\
\text { ortalama }\end{array}$ & $\begin{array}{l}\text { En } \\
\text { düşük }\end{array}$ & $\begin{array}{l}\text { En } \\
\text { yükssek }\end{array}$ & Basıklık & Çarpıklık \\
\hline $\begin{array}{l}\text { Kimya Dersine } \\
\text { Olumsuz Duygu }\end{array}$ & Dönük & 2.98 & .51 & 2.99 & 1.80 & 3.90 & -.809 & -.062 \\
\hline $\begin{array}{l}\text { Kimya Dersine } \\
\text { Olumlu Duygu }\end{array}$ & Dönük & 2.26 & .47 & 2.26 & 1.43 & 3.14 & -1.050 & .029 \\
\hline $\begin{array}{l}\text { Kimya Dersine } \\
\text { Faaliyet }\end{array}$ & Dönük & 2.34 & .44 & 2.33 & 1.40 & 3.60 & -.294 & .219 \\
\hline $\begin{array}{l}\text { Kimya Dersine } \\
\text { Tutum Ölçeği }\end{array}$ & Yönelik & 2.61 & .39 & 2.61 & 1.91 & 3.27 & -1.377 & .065 \\
\hline
\end{tabular}

Tablo 1 incelendiğinde verilerin basıklık ve çarpıklık değerleri +1.5 ile -1.5 arasındadır, asıl ortalama ile budanmış ortalama kıyaslandığında bu iki ortalama değerinin birbirinden çok farklı olmadığ dikkati çekmektedir. Buna göre veri seti betimsel yöntemlere göre normal dağılım göstermektedir (Tabachnick ve Fidell, 2013).

Grafiksel yöntemlerde, puanların dağılımı görsel olarak sunulur, burada puanların bir doğru üzerindeki konumu belirlenir (McKillup, 2012). Değerlerin kontrol edilmesi için öncelikle 
normal Q-Q plot ve eğilimden arındırılmış Q-Q grafiğine bakılmıştır. Grafiksel yöntemlere ait sonuçlar Şekil 1'de özetlenmektedir.
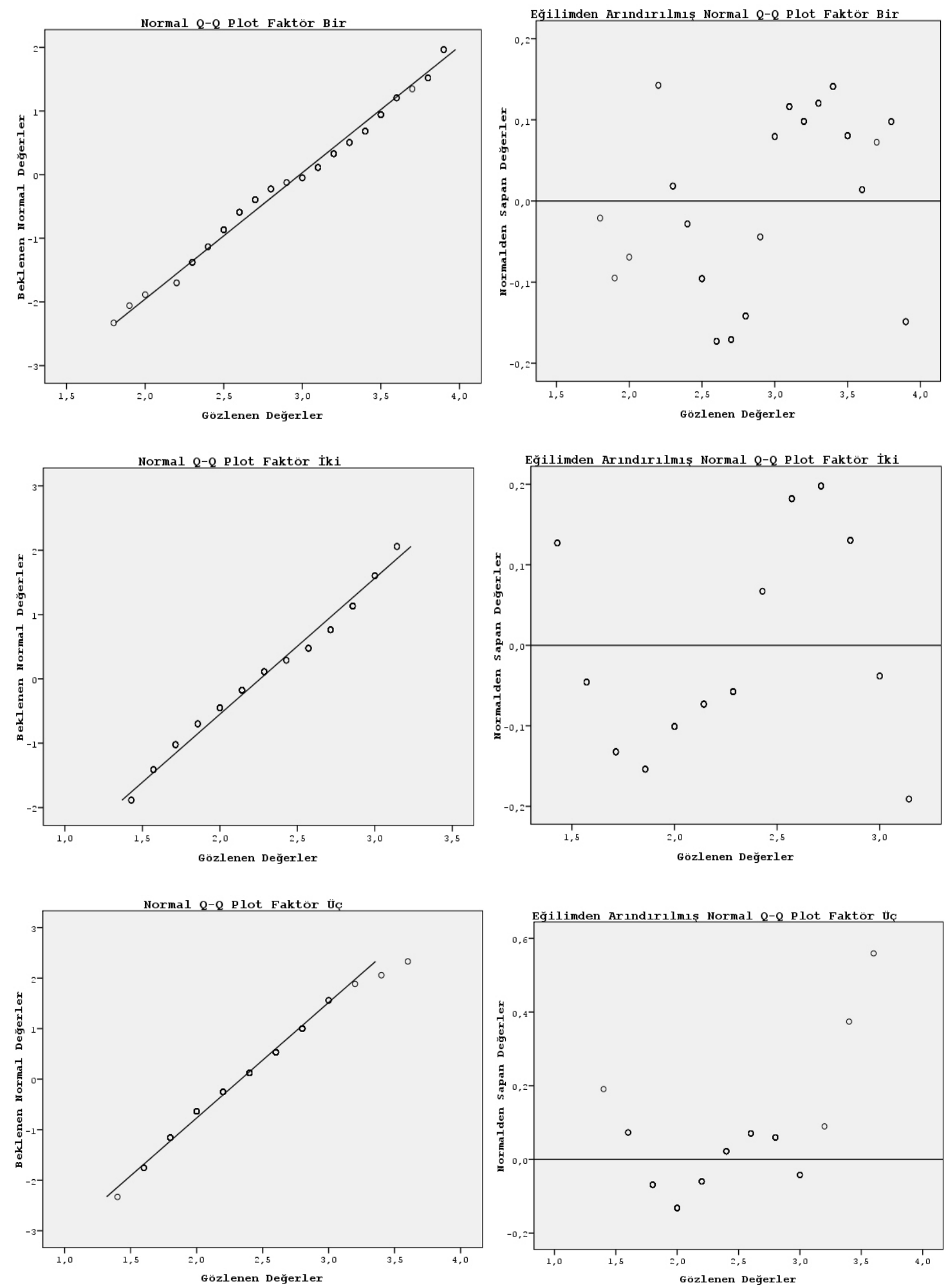

Şekil 2. Kimya Dersine Yönelik Tutum Ön-test Ölçümlerine İlişkin Normallik Varsayımı Grafiksel Yöntemler 
Şekil 2 incelendiğinde normal Q-Q grafiği ve eğilimden arındırılmış Q-Q grafiğine göre dağılımın normalliğini etkileyecek bir durum söz konusu değildir. Kimya dersine yönelik tutum verileri grafiksel yöntemlere göre normal dağılım göstermektedir.

İstatistiksel yöntemlerde normallik için Shapiro-Wilks Testi ve Kolmogorov-Smirnov Testi kullanılır (Abbott, 2011). İstatistiksel yöntemlere ilişkin sonuçlar Tablo 2'de verilmektedir.

Tablo 2. Kimya Dersine Yönelik Tutum Ön-test Ölçümlerine İlişkin Normallik Varsayımı İstatistiksel Yöntemler

\begin{tabular}{lllllll}
\hline & \multicolumn{3}{c}{ Kolmogorov Smirnov } & \multicolumn{3}{c}{ Shapiro-Wilk } \\
& İstatistik & $\mathrm{df}$ & $\mathrm{p}$ & İstatistik & $\mathrm{df}$ & $\mathrm{p}$ \\
\hline Kimya Dersine Dönük Olumsuz Duygu & .094 & 100 & .029 & .973 & 100 & .037 \\
Kimya Dersine Dönük Olumlu Duygu & .115 & 100 & .002 & .959 & 100 & .003 \\
Kimya Dersine Dönük Faaliyet & .119 & 100 & .001 & .970 & 100 & .021 \\
Kimya Dersine Yönelik Tutum Ölçeği & .124 & 100 & .001 & .956 & 100 & .002 \\
\hline${ }^{*} \mathrm{p}>0.05$ & & & & & &
\end{tabular}

Verilerin normal dağılım sayıltısını karşılaması için p değerinin anlamlı olmaması gerekir, ancak söz konusu büyük örneklemlerde bu durum sıklıkla görülmektedir. Veriler normal dağılımdan önemli bir sapma göstermediği için tek değişkenli normallik varsayımı karşılanmaktadır.

Çok değişkenli normallik ve uç değerler olup olmadığını gözlemek için asıl ortalama ile budanmış ortalama kıyaslanmış (Tablo 1), bu iki ortalama değeri birbirinden çok farklıysa uç değerlerin kontrol edilmesi için öncelikle Q-Q plot'a bakılmıştır. Buradan uç değer olup olmadığı belirlenirse Mahalanobis uzaklık değeri incelenir. Tablo 1 incelediğinde ortalama ve budanmış ortalama değerleri arasında çok az farklar olduğu görülmektedir. Uç değerler olabileceği düşünülerek Q-Q plot incelenmiştir. Çok değişkenli normal dağılıma göre veriler normal Q-Q grafiğinde normal dağılımdan çok az sapmalar göstermekte, eğilimden arındırılmış Normal Q-Q grafiğinde ise sıfır çizgisi etrafında az sayıda nokta kümeleri olduğu dikkati çekmiştir (Şekil 1). Q-Q plots grafiğinden elde edilen bilgilerden yararlanılarak veri seti için Mahalanobis uzaklığı kullanılarak çok değişkenli normal dağılım kontrol edilmiştir. Mahalanobis uzaklığı kritik değerin üzerinde olan uç değer olup olmadığı belirlenmiştir. Söz konusu çalışmada bağımlı değişken sayısı 3 olduğu için kritik değer 16.27'dir (Tabachnick ve Fidell, 2013). Buna göre veri dosyasında Mahalanobis uzaklığı kritik değerin üzerinde olan uç değer bulunmamaktadır. MANOVA'nın çok değişkenli normallik varsayımı karşılamaktadır.

\subsection{Varyans-Kovaryans Matrislerinin Homojenliği Varsayımı}

Varyans-kovaryans matrislerinin homojenliği sayıltısını incelemek için Box’s M testi ve Levene testlerine bakılmıştır. Kovaryans matrislerinin homojenliği varsayımının karşılanması için yapılan analizde Box's M testinin istatistiksel olarak anlamlı olmaması gerekir. Eğer bu değer anlamlı ise varsayım ihlal ediliyor demektir. Araştırmada kimya dersine dönük olumsuz duygu, kimya dersine dönük olumlu duygu ve kimya dersine dönük faaliyet değişkenlerinden oluşan bağımlı değişken veri seti için hesaplanan Box's M testine ilişkin anlamlılık değeri uygulama grubu için [Box's $\mathrm{M}=19.129, \mathrm{~F}_{(18.32566)}$ :1.002, $\mathrm{p}>0.05$ ]'dir. Buna göre uygulama grubu bağımsız değişkeni için kovaryans matrislerinin homojenliği varsayımı karşılanmıştır, bu varsayım ihlal edilmemektedir. MANOVA analizi yorumlanırken kovaryans matrislerinin homojenliği varsayımının karşılandığını için Wilks' Lambda değerine bakılmıştır (Tabachnick ve Fidell, 2013). Manova'nın diğer bir sayıltısı varyansların homojenliğidir. Varyansların eşitliği için Levene testine bakılmıştır ve bağımlı değişkenler açısından varyansların eşitliği [p>.05] kabul edilmiştir. 
Tablo 3. Kimya Dersine Yönelik Tutum Ön-test Ölçümlerine İlişkin Varyansların Homojenliğine İlişkin Levene's Test Sonuçları

\begin{tabular}{lcccc}
\hline & $\mathrm{sd} 1$ & $\mathrm{sd} 2$ & $\mathrm{~F}$ & $\mathrm{p}$ \\
\hline Kimya Dersine Dönük Olumsuz Duygu & 3 & 96 & .640 & .591 \\
Kimya Dersine Dönük Olumlu Duygu & 3 & 96 & .865 & .462 \\
Kimya Dersine Dönük Faaliyet & 3 & 96 & .156 & .926 \\
\hline${ }^{*} \mathrm{p}>0.05$ & & &
\end{tabular}

Tablo 3 incelendiğinde kimya dersine yönelik tutum ön-test puanları açısından varyansların homojenliği varsayımının karşılandığı görülmektedir ( $\mathrm{p}>0.05)$.

\section{3. Çoklu Ortak Doğrusallık Sayıltısı}

Çoklu ortak doğrusallık korelasyon ile kontrol edilmiştir. Bağımlı değişkenler arasındaki korelasyon katsayısının 0.800 ve üzerinde olması çoklu ortak doğrusallık problemine işaret eder (Pallant, 2005).

Tablo 4. Kimya Dersine Yönelik Tutum Ön-test Ölçeğinin Alt Boyutları Arasındaki İlişki

\begin{tabular}{|c|c|c|c|c|}
\hline & & $\begin{array}{c}\text { Kimya Dersine } \\
\text { Dönük Olumsuz } \\
\text { Duygu }\end{array}$ & $\begin{array}{c}\text { Kimya Dersine } \\
\text { Dönük Olumlu } \\
\text { Duygu }\end{array}$ & $\begin{array}{l}\text { Kimya Dersine } \\
\text { Dönük Faaliyet }\end{array}$ \\
\hline \multirow{3}{*}{$\begin{array}{l}\text { Kimya Dersine } \\
\text { Dönük Olumsuz } \\
\text { Duygu }\end{array}$} & $\begin{array}{l}\text { Pearson } \\
\text { korelasyon }\end{array}$ & (n) & $.587 * *$ & $.368 * *$ \\
\hline & Sig. (2-tailed) & & .000 & .000 \\
\hline & $\mathrm{N}$ & 100 & 100 & 100 \\
\hline \multirow{3}{*}{$\begin{array}{l}\text { Kimya Dersine } \\
\text { Dönük Olumlu } \\
\text { Duygu }\end{array}$} & $\begin{array}{l}\text { Pearson } \\
\text { korelasyon }\end{array}$ & $.587 * *$ & 1 & $.297 * *$ \\
\hline & Sig. (2-tailed) & .000 & & .003 \\
\hline & $\mathrm{N}$ & 100 & 100 & 100 \\
\hline \multirow{3}{*}{$\begin{array}{l}\text { Kimya Dersine } \\
\text { Dönük Faaliyet }\end{array}$} & $\begin{array}{l}\text { Pearson } \\
\text { korelasyon }\end{array}$ & $.368 * *$ & $.297 * *$ & 1 \\
\hline & Sig. (2-tailed) & .000 & .003 & \\
\hline & $\mathrm{N}$ & 100 & 100 & 100 \\
\hline
\end{tabular}

** $\mathrm{p} \leq .001$ düzeyinde anlamlıdır.

Araştırmada kimya dersine dönük olumsuz duygu, kimya dersine dönük olumlu duygu ve kimya dersine dönük faaliyet değişkenleri arasındaki korelasyon katsayısı Tablo 4'te görülmektedir. Buna göre bağımlı değişkenler arasında çoklu ortak doğrusallık yoktur ve veri seti bu varsayımı karşılamaktadır.

\section{Kimya Dersine Yönelik Tutum Ön-Test MANOVA Bulguları}

Yapılan analizler sonucuna göre MANOVA'nın varsayımsal kriterleri taşınmaktadır. Buna göre kimya dersine yönelik tutum ölçeğinin kimya dersine dönük olumsuz duygu, kimya dersine dönük olumlu duygu ve kimya dersine dönük faaliyet bağımlı değişkenleri ön-testleri arasında uygulama grubuna göre farklılık olup olmadığı MANOVA ile incelenmiştir. Sonuçlar Tablo 5 'te verilmektedir.

Tablo 5. Kimya Dersine Yönelik Tutum Ön-test Puanlarının MANOVA Analizi

\begin{tabular}{|c|c|c|c|c|c|c|c|}
\hline & Etkileşim & Değer & $\mathrm{F}$ & Hipotez Sd & Hata Sd & $\mathrm{p}^{*}$ & $\eta^{2}$ \\
\hline Gruplar & Wilks' Lambda & .228 & 21.275 & 9 & 228 & .000 & .389 \\
\hline
\end{tabular}


deney1, deney2 kontrol1 ve kontrol2 grubundaki öğrenciler arasında anlamlı farklılık bulunmaktadır.

MANOVA'ya göre belirlenen anlamlı farkında hangi alt boyut ya da boyutlarda ortaya çıktığını belirlemek için ANOVA testi uygulanmış ve Tukey çoklu karşılaştırma testi verileri kullanılmıştır. Analiz sonuçları Tablo 6'da verilmiştir.

Tablo 6. Kimya Dersine Yönelik Tutum Ön-test Alt Boyutları Varyans Analizi Sonuçları

\begin{tabular}{llllllll}
\hline $\begin{array}{l}\text { Varyansın } \\
\text { Kaynağ1 }\end{array}$ & $\begin{array}{l}\text { Bağımlı } \\
\text { Değişken }\end{array}$ & Kareler Toplamı & Sd & $\begin{array}{l}\text { Ortalamalar } \\
\text { Karesi }\end{array}$ & F & $\mathrm{p}$ & $\eta^{2}$ \\
\hline \multirow{3}{*}{ Grup } & Faktör 1 & 15.134 & 3 & 5.045 & 48.363 & .000 & .602 \\
& Faktör 2 & 12.758 & 3 & 4.253 & 43.527 & .000 & .576 \\
& Faktör 3 & 4.374 & 3 & 1.458 & 9.604 & .000 & .231 \\
\hline
\end{tabular}

Analiz sonuçlarına göre uygulama grubu bağımsız değişkeninin kimya dersine dönük olumsuz duygu, kimya dersine dönük olumlu duygu ve kimya dersine dönük faaliyet bağımlı değişkenleri üzerinde anlamlı etkiye sahip olduğu görülmektedir. Ölçeğin hangi boyut ya da boyutlarında hangi gruplar arasında anlamlı farklılık olduğunu belirlemek için yapılan Tukey testi sonuçlarına göre kimya dersine dönük olumsuz duygu boyutunda deney grubu 1 (X:2.59) ile kontrol grubu 1 (X:3.31) ve deney grubu 1 (X:2.59) ile kontrol grubu 2 (X:3.43) arasinda, deney grubu 2 (X:2.60) ile kontrol grubu 1 (X:3.31) ve deney grubu 2 (X:2.60) ile kontrol grubu 2 (X:3.43) arasındadır. Ölçeğin kimya dersine dönük olumlu duygu boyutunda deney grubu 1 (X:1.94) ile kontrol grubu 1 (X:2.69) ve deney grubu 1 (X:1.94) ile kontrol grubu 2 (X:2.53) arasinda ve deney grubu 2 (X:1.88) ile kontrol grubu 1 (X:2.69) ve deney grubu 2 (X:1.88) ile kontrol grubu 2 (X:2.53) arasındadır. Ölçeğin kimya dersine dönük faaliyet boyutunda deney grubu 1 (X:2.20) ile kontrol grubu 1 (X:2.62) arasında ve deney grubu 2 (X:2.08) ile kontrol grubu 1 (X:2.62) ve deney grubu 2 (X:2.08) ile kontrol grubu 2 (X:2.45) arasindadır.

\section{Kimya Dersine Yönelik Tutum Son-Test Bulguları}

TGA destekli uygulama sonrasında örneklem grubunun kimya dersine yönelik tutum sontest puanları arasında fark olup olmadığı MANOVA ile incelenmiştir. Kimya dersine yönelik tutum son-test verilerinin MANOVA'nın sayıltılarını karşılayıp karşılamadığı incelenmiştir. Bu amaçla tek değişkenli ve çok değişkenli normal dağılım, varyans-kovaryans matrislerinin homojenliği ve çoklu ortak doğrusallık test edilmiştir. Kimya dersine yönelik tutum ölçeğinden elde edilen son-test verilerinin tek ve çok değişkenli normallik varsayımını karşılayıp karşılamadığı betimsel, grafiksel ve istatistiksel olarak incelenmiştir. Betimsel yöntemlerde aritmetik ortalama, standart sapma, çarpıklık ve basıklık katsayıları gibi istatistikler incelenmiştir. Sonuçlar Tablo 7'de verilmektedir.

Tablo 7. Kimya Dersine Yönelik Tutum Son-test Ölçümleri Tüm Gruplara İlişkin Normallik Varsayımı Betimsel Yöntemler

\begin{tabular}{|c|c|c|c|c|c|c|c|c|}
\hline & & $\overline{\mathrm{x}}$ & Ss & $\begin{array}{c}5 \% \\
\text { Budanmış } \\
\text { ortalama }\end{array}$ & $\begin{array}{l}\text { En } \\
\text { düşük }\end{array}$ & $\begin{array}{c}\text { En } \\
\text { yüksek }\end{array}$ & Basıklık & Çarpıklık \\
\hline $\begin{array}{l}\text { Kimya Dersine } \\
\text { Olumsuz Duygu }\end{array}$ & Dönük & 3.61 & .43 & 3.62 & 2.40 & 4.50 & .327 & -.446 \\
\hline $\begin{array}{l}\text { Kimya Dersine } \\
\text { Olumlu Duygu }\end{array}$ & Dönük & 3.15 & .60 & 3.15 & 2.00 & 4.29 & -.898 & .111 \\
\hline $\begin{array}{l}\text { Kimya Dersine } \\
\text { Faaliyet }\end{array}$ & Dönük & 3.19 & .69 & 3.19 & 1.60 & 4.60 & -.898 & -.011 \\
\hline $\begin{array}{l}\text { Kimya Dersine } \\
\text { Tutum Ölçeği }\end{array}$ & Yönelik & 3.37 & .43 & 3.38 & 2.36 & 4.23 & -1.085 & -.038 \\
\hline
\end{tabular}


Tablo 7 incelendiğinde verilerin basıklık ve çarpıklık değerleri +1.5 ile -1.5 arasında olduğu, asıl ortalama ile budanmış ortalama kıyaslandığında bu iki ortalama değerinin birbirinden çok farklı olmadığı ve veri setinin normal dağılım gösterdiği görülmektedir.

Grafiksel yöntemlere ait sonuçlar Şekil 3'te özetlenmektedir.
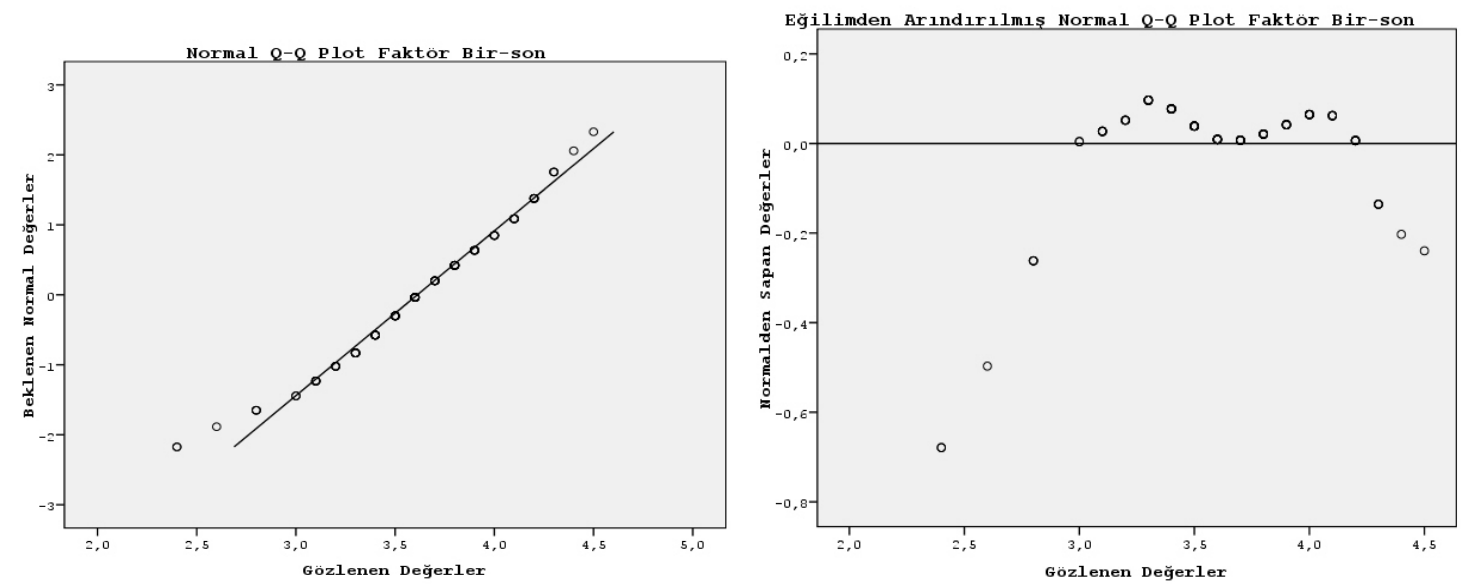

Normal Q-Q Plot Faktör İki-son
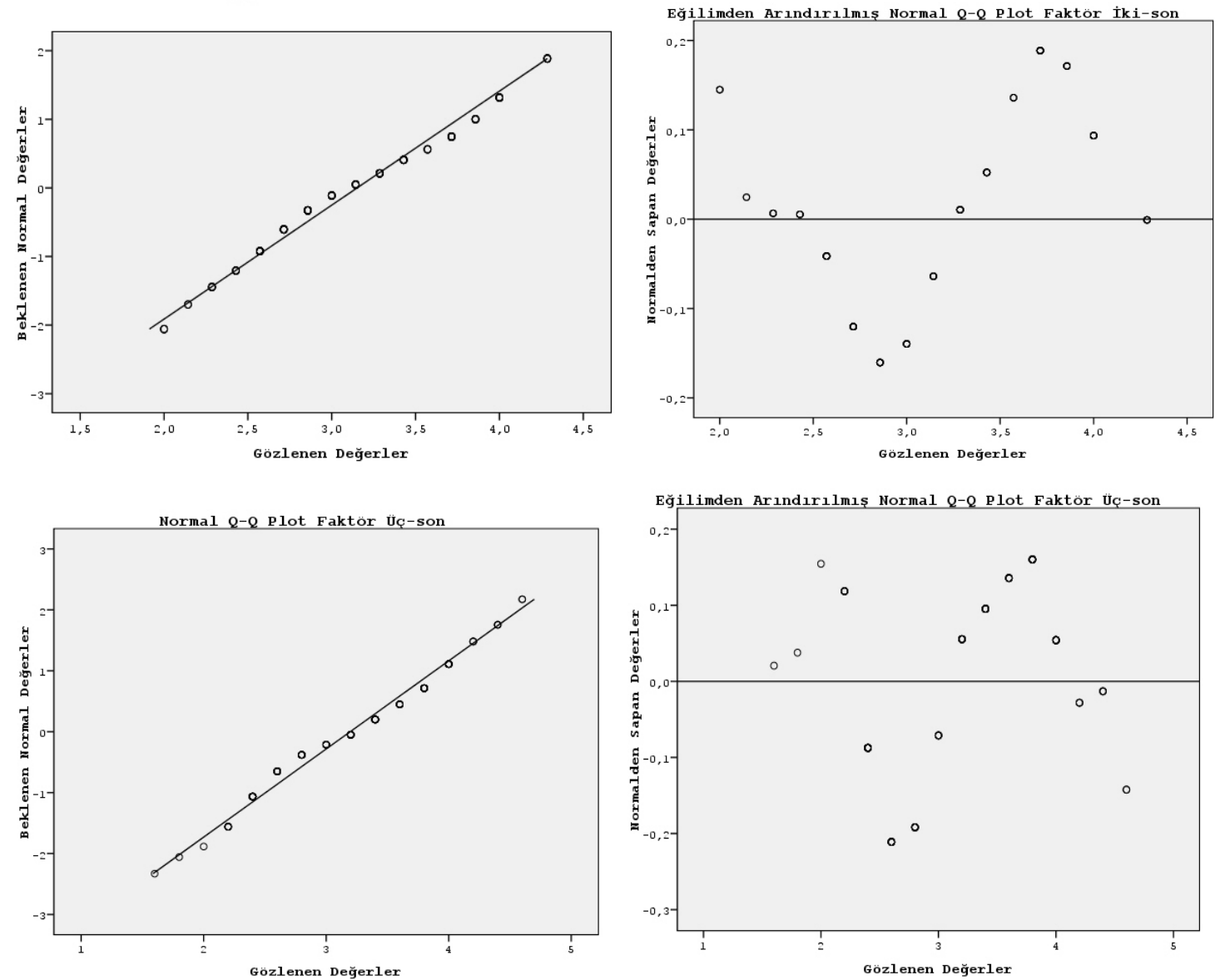

Şekil 3. Kimya Dersine Yönelik Tutum Son-test Ölçümlerine İlişsin Normallik Varsayımı Grafiksel Yöntemler

Şekil 3 incelendiğinde normal Q-Q grafiği ve eğilimden arındırılmış Q-Q grafiğine göre dağılımın normalliğini etkileyecek bir durum söz konusu değildir. Kimya dersine yönelik tutum son-test verileri normal dağılım göstermektedir. 
İstatistiksel yöntemlere ilişkin sonuçlar Tablo 8'de verilmektedir.

Tablo 8. Kimya Dersine Yönelik Tutum Son-test Ölçümlerine İlişkin Normallik Varsayımı İstatistiksel Yöntemler

\begin{tabular}{|c|c|c|c|c|c|c|}
\hline & \multicolumn{3}{|c|}{ Kolmogorov Smirnov } & \multicolumn{2}{|c|}{ Shapiro-Wilk } & \multirow[b]{2}{*}{$\mathrm{p}$} \\
\hline & İstatistik & $\mathrm{df}$ & $\mathrm{p}$ & İstatistik & df & \\
\hline $\begin{array}{l}\text { Kimya Dersine Dönük } \\
\text { Olumsuz Duygu }\end{array}$ & .079 & 100 & 128 & .978 & 100 & .091 \\
\hline $\begin{array}{l}\text { Kimya Dersine Dönük } \\
\text { Olumlu Duygu }\end{array}$ & 108 & 100 & .006 & .968 & 100 & .015 \\
\hline $\begin{array}{l}\text { Kimya Dersine Dönük } \\
\text { Faaliyet }\end{array}$ & 116 & 100 & .002 & .968 & 100 & .015 \\
\hline $\begin{array}{l}\text { Kimya Dersine Yönelik } \\
\text { Tutum Ölçeği }\end{array}$ & .122 & 100 & .001 & .956 & 100 & .002 \\
\hline
\end{tabular}

Tablo 8 incelendiğinde verilerin normal dağılımdan önemli bir sapma göstermemektedir. Tek değişkenli normallik varsayımı karşılanmaktadır.

Çok değişkenli normallik ve uç değerler olup olmadığını gözlemek için asıl ortalama ile budanmış ortalama kıyaslanmış (Tablo 7), bu iki ortalama değeri birbirinden çok farklıysa uç değerlerin kontrol edilmesi için öncelikle Q-Q plot'a bakılmıştır. Buna göre MANOVA'nın çok değişkenli normallik varsayımı karşılamaktadır.

Varyans-kovaryans matrislerinin homojenliği sayıltısını incelemek için Box's M testi ve Levene testlerine bakılmıştır. Araştırmada kimya dersine dönük olumsuz duygu, kimya dersine dönük olumlu duygu ve kimya dersine dönük faaliyet değişkenlerinden oluşan bağımlı değişken son-test veri seti için hesaplanan Box's M testine ilişkin anlamlılık değeri uygulama grubu için [Box's $\mathrm{M}=9.188, \mathrm{~F}_{(18.32566)}: .481, \mathrm{p}=0.967, \mathrm{p}>0.05$ ]. Buna göre uygulama grubu bağımsız değişkeni için kovaryans matrislerinin homojenliği varsayımı karşılanmıştır, bu varsayım ihlal edilmemektedir. MANOVA analizi yorumlanırken kovaryans matrislerinin homojenliği varsayımının karşılandığını için Wilks' Lambda değerine bakılmıştır. Manova'nın diğer bir sayıltısı varyansların homojenliğidir. Varyansların eşitliği için Levene testine bakılmıştır ve bağımlı değişkenler açısından varyansların eşitliği [p>.05] kabul edilmiştir.

Tablo 9. Kimya Dersine Yönelik Tutum Son-test Ölçümlerine İlişkin Varyansların Homojenliğine İlişkin Levene's Test Sonuçları

\begin{tabular}{lcccc}
\hline & sd1 & sd2 & F & $\mathrm{p}$ \\
\hline Kimya Dersine Dönük Olumsuz Duygu & 3 & 96 & 1.882 & .138 \\
Kimya Dersine Dönük Olumlu Duygu & 3 & 96 & 2.145 & .100 \\
Kimya Dersine Dönük Faaliyet & 3 & 96 & .136 & .938 \\
\hline$*_{p}>0.05$
\end{tabular}

Tablo 9 incelendiğinde kimya dersine yönelik tutum son-test puanları açısından varyansların homojenliği varsayımı karşılanmaktadır ( $p>0.05)$.

Çoklu ortak doğrusallık korelasyon ile kontrol edilmiştir. Sonuçlar Tablo 10' da verilmektedir. 
Tablo 10. Kimya Dersine Yönelik Tutum Son-test Ölçeğinin Alt Boyutları Arasındaki İlişki

\begin{tabular}{|c|c|c|c|c|}
\hline & & $\begin{array}{c}\text { Kimya Dersine } \\
\text { Dönük Olumsuz } \\
\text { Duygu }\end{array}$ & $\begin{array}{c}\text { Kimya Dersine } \\
\text { Dönük Olumlu } \\
\text { Duygu }\end{array}$ & $\begin{array}{l}\text { Kimya Dersine } \\
\text { Dönük Faaliyet }\end{array}$ \\
\hline \multirow{3}{*}{$\begin{array}{l}\text { Kimya Dersine Dönük } \\
\text { Olumsuz Duygu }\end{array}$} & $\begin{array}{l}\text { Pearson } \\
\text { korelasyon }\end{array}$ & 1 & $.463 * *$ & $.459 * *$ \\
\hline & Sig. (2-tailed) & & .000 & .000 \\
\hline & $\mathrm{N}$ & 100 & 100 & 100 \\
\hline \multirow{3}{*}{$\begin{array}{l}\text { Kimya Dersine Dönük } \\
\text { Olumlu Duygu }\end{array}$} & $\begin{array}{l}\text { Pearson } \\
\text { korelasyon }\end{array}$ & $.463 * *$ & 1 & $.409 * *$ \\
\hline & Sig. (2-tailed) & .000 & & .000 \\
\hline & $\mathrm{N}$ & 100 & 100 & 100 \\
\hline \multirow{3}{*}{$\begin{array}{l}\text { Kimya Dersine Dönük } \\
\text { Faaliyet }\end{array}$} & $\begin{array}{l}\text { Pearson } \\
\text { korelasyon }\end{array}$ & $.459 * *$ & $.409 * *$ & 1 \\
\hline & Sig. (2-tailed) & .000 & .000 & \\
\hline & $\mathrm{N}$ & 100 & 100 & 100 \\
\hline
\end{tabular}

** $\mathrm{p} \leq .001$ düzeyinde anlamlıdır.

Tablo 10'da değişkenleri arasındaki korelasyon katsayısı görülmektedir. Buna göre bağımlı değişkenler arasında çoklu ortak doğrusallık yoktur ve veri seti bu varsayımı karşılamaktadır.

TGA destekli uygulama sonrasında kimya dersine yönelik tutum son-test puanları MANOVA'nın sayıltılarını karşılamaktadır. Kimya dersine yönelik tutum ölçeğinin kimya dersine dönük olumsuz duygu, kimya dersine dönük olumlu duygu ve kimya dersine dönük faaliyet bağımlı değişkenlerinde uygulama grubuna göre farklılık olup olmadığ için MANOVA analizine geçilmiştir. Ancak uygulama öncesinde örneklem grubunun kimya dersine yönelik tutum öntest puanları uygulama grubuna göre anlamlı farklılık göstermektedir. İstatistiksel olarak kimya dersine yönelik tutum puanları ön-testte gözlenen bu anlamlı fark öğrencilerin sontest puanlarını etkileyecektir. MANOVA analizi yapılırken kimya dersine yönelik tutum puanları ön-testte gözlenen anlamlı farkın son-test üzerindeki etkisi kontrol altında tutulmuştur. TGA destekli uygulama sonrasında deney ve kontrol gruplarındaki öğrencilerin, ön-test, sontest ve ön-teste göre düzeltilmiş son-test ortalama puanları Tablo 11'de verilmiştir.

Tablo 11. Kimya Derine Yönelik Tutum Son-Test Puanlarının Uygulama Gruplarına Göre Betimsel İstatistik Sonuçları

\begin{tabular}{lllll}
\hline & Grup & Ön-Test & Son-Test & Düzeltilmiş \\
\hline Kimya Dersine Dönük & Deney Grubu 1 & 2.59 & 3.83 & 4.07 \\
Olumsuz Duygu & Deney Grubu 2 & 2.60 & 3.96 & 4.21 \\
& Kontrol Grubu 1 & 3.32 & 3.31 & 3.06 \\
Kimya Dersine Dönük & Kontrol Grubu 2 & 3.43 & 3.36 & 3.11 \\
Olumlu Duygu & Deney Grubu 1 & 1.94 & 3.54 & 3.66 \\
& Deney Grubu 2 & 1.88 & 3.60 & 3.73 \\
& Kontrol Grubu 1 & 2.69 & 2.67 & 2.52 \\
Kimya Dersine Dönük & Kontrol Grubu 2 & 2.53 & 2.79 & 2.69 \\
Faaliyet & Deney Grubu 1 & 2.20 & 3.66 & 3.62 \\
& Deney Grubu 2 & 2.08 & 3.74 & 3.69 \\
& Kontrol Grubu 1 & 2.62 & 2.62 & 2.69 \\
& Kontrol Grubu 2 & 2.45 & 2.78 & 2.78 \\
\hline
\end{tabular}

MANOVA sonuçları Tablo 12'de verilmektedir. 
Tablo 12. Kimya Dersine Yönelik Tutum Son-test Puanlarının MANOVA Analizi

\begin{tabular}{llllllll}
\hline & Etkileşim & Değer & F & Hipotez Sd & Hata Sd & $p^{*}$ & $\eta^{2}$ \\
\hline Gruplar & Wilks' Lambda & .319 & 14.770 & 9 & 221 & .000 & .317 \\
\hline${ }^{p}<0.001$ & & & & & & &
\end{tabular}

Tablo 12 incelendiğinde MANOVA sonuçlarına göre lise öğrencilerinin kimya dersine yönelik tutum ön-test puanları kontrol altına alındığında, uygulama grubuna göre son-test puanları arasında istatistiksel olarak farklılığın anlamlı olduğu belirlenmiştir [(Wilks' Lambda $=.319$, $\left.\left.\mathrm{F}_{(9,221)}=14.770, \eta^{2}=.317, \mathrm{p}<.001\right)\right]$, kimya dersine yönelik tutum ölçeği son-test puanları bakımından deney 1 , deney 2, kontrol 1 ve kontrol 2 grubundaki öğrenciler arasında anlamlı farklılık bulunmaktadır.

MANOVA'ya göre belirlenen anlamlı farkında hangi alt boyut ya da boyutlarda ortaya çıktığını belirlemek için ANOVA testi uygulanmış ve Tukey çoklu karşılaştırma testi verileri kullanılmıştır. Analiz sonuçları Tablo 13’te verilmiştir.

Tablo 13. Kimya Dersine Yönelik Tutum Son-test Alt Boyutları Varyans Analizi Sonuçları

\begin{tabular}{cccccccc}
\hline $\begin{array}{c}\text { Varyansın } \\
\text { Kaynağı }\end{array}$ & $\begin{array}{c}\text { Bağımlı } \\
\text { Değişken }\end{array}$ & $\begin{array}{c}\text { Kareler } \\
\text { Toplamı }\end{array}$ & Sd & $\begin{array}{c}\text { Ortalamalar } \\
\text { Karesi }\end{array}$ & F & p & $\eta^{2}$ \\
\hline \multirow{3}{*}{ Grup } & Faktör 1 & 7.146 & 3 & 2.382 & 29.878 & .000 & .491 \\
& Faktör 2 & 7.596 & 3 & 2.532 & 16.040 & .000 & .341 \\
& Faktör 3 & 5.266 & 3 & 1.755 & 8.401 & .000 & .213 \\
\hline
\end{tabular}

Analiz sonuçlarına göre uygulama grubu bağımsız değişkeninin kimya dersine dönük olumsuz duygu (Faktör 1), kimya dersine dönük olumlu duygu (Faktör 2) ve kimya dersine dönük faaliyet (Faktör 3) bağımlı değişkenleri üzerinde anlamlı etkiye sahip olduğu görülmektedir. Ölçeğin hangi boyut ya da boyutlarında hangi gruplar arasında fark olduğunu belirlemek için yapılan Tukey testi sonuçlarına göre kimya dersine dönük olumsuz duygu boyutunda deney grubu 1 (X:4.07) ile kontrol grubu 1 (X:3.06) ve deney grubu 1 (X:4.07) ile kontrol grubu 2 (X:3.11) arasinda, deney grubu 2 (X:4.21) ile kontrol grubu 1 (X:3.06) ve deney grubu 2 (X:4.21) ile kontrol grubu 2 (X:3.11) arasındadır. Ölçeğin kimya dersine dönük olumlu duygu boyutunda deney grubu 1 (X:3.66) ile kontrol grubu 1 (X:2.52) ve deney grubu 1 (X:3.66) ile kontrol grubu 2 (X:2.69) arasinda ve deney grubu 2 (X:3.73) ile kontrol grubu 1 (X:2.52) ve deney grubu 2 (X:3.73) ile kontrol grubu 2 (X:2.69) arasındadır. Ölçeğin kimya dersine dönük faaliyet boyutunda deney grubu 1 (X:3.62) ile kontrol grubu 1 (X:2.69) ve deney grubu 1 (X:3.62) ile kontrol grubu 2 (X:2.78) arasinda ve deney grubu 2 (X:3.69) ile kontrol grubu 1 (X:2.69) ve deney grubu 2 (X:3.69) ile kontrol grubu 2 (X:2.78) arasındadır.

\section{TARTIŞMA VE SONUÇ}

Araştırmada Endüstri ve Canlılarda Enerji ünitesinin Hidrokarbonlar konusunda TGA destekli çalışma yaprakları ile öğretimin lise 10. sınıf öğrencilerinin kimya dersine yönelik tutumları üzerine etkisi incelenmiştir. Hidrokarbonlar konusu deney gruplarında TGA yöntemine uygun çalışma yaprakları ile işlenirken, kontrol gruplarında ise soru-cevap tekniği ve sunumlarla desteklenen geleneksel yöntem ile işlenmiştir. Kimya dersine yönelik tutum alt boyutlarında deney/kontrol grubuna göre farklılık olup olmadığı MANOVA ile incelenmiştir. İlk olarak deney ve kontrol gruplarındaki öğrencilerin kimya dersine yönelik tutum alt boyutları öntest puanları arasında anlamlı fark olup olmadığı kontrol edilmiştir. Analiz sonucunda öntestlerde anlamlı farklılık bulunmuştur. Öntestteki bu anlamlı farkl1lık sontest analizlerini de etkileyecektir. Bu nedenle analiz yapılırken kimya dersine yönelik tutum puanları ön-testte gözlenen anlamlı farkın son-test üzerindeki etkisi kontrol altında tutulmuştur. Analiz sonucunda göre ölçeğin tüm alt boyutlarında deney ve kontrol grupları arasında anlamlı farklılık vardır. 
Buna göre TGA destekli çalışma yapraklarının uygulandığı deney 1 ve 2 gruplarının kimya dersine yönelik tutum ölçeğinin tüm alt boyutlarındaki ortalamaları kontrol 1 ve 2 gruplarınınkinden daha yüksektir ve ortalamalar arasındaki fark istatistiksel olarak anlamlıdır. TGA destekli materyaller öğrencilerin kimya tutumlarını artırmada etkili olmuştur. Literatür incelendiğinde TGA'nın tutum üzerinde olumlu etkisi bulgusu diğer çalışmalarla da benzerlik göstermektedir.

TGA yöntemi öğrencilerin çözünürlüğe etki eden faktörler konusundaki kavramsal anlamalarını artırırken, konunun akılda kalıcı olmasını, ilgi çekici ve daha anlamlı öğrenmelerin gerçekleştiği bildirilmektedir (Rusçuklu ve Özdilek, 2019). TGA yönteminin öğrencilerin performanslarını artırmada etkili olduğu (McGregor ve Hargrave, 2008), TGA destekli uygulamaların öğrencilerin fen öğrenmeye yönelik ilgilerini artırmak ve devamlılığı da sağlamakta başarılı olduğu belirlenmiştir (Hong, Hwang, Liu, Ho ve Chen 2014). TGA yönteminin kimya dersinde öğrencilerin başarı ve performanslarına olumlu etkilerini belirlenmiş ve farklı branș derslerinde de bu yöntemin uygulanabileceği bildirilmiştir (Sreerekha, Raj ve Sankar, 2016). TGA uygulanan grupların bilimsel tutumları geleneksel yöntem uygulanan gruplara göre daha fazla olduğu (Muhibbuddin, Ilyas ve Para Samya, 2019), tahmin et-gözleaçıkla stratejisine göre hazırlanan deneylerin öğrencilerin, fen laboratuvarında deney yapmaktan zevk aldıkları ortaya çıkmıştır (Tekin, 2008). TGA'ya göre hazırlanan laboratuvar etkinliklerinin bireyleri zorladığ belirtilirken, etkinliklerin kendi yetenek ve öğrenmeleri geliştirici yönde teşvik ettiğinden dolayı mutlu ettiği de ifade edilmektedir (Bilen, 2009), ayrıca TGA yöntemi öğrencilerin bir yandan başarılarını artırırken diğer yandan derse yönelik tutumlarının gelişmesini de sağlamaktadır (Chew, 2008). TGA destekli öğretimin öğrencilerin davranış, tutum ve başarı sonuçlarına olumlu yönde katkı sağladığı tespit edilmiştir (Güven, 2011).

TGA tekniğinin laboratuvar ortamında uygulanmasında başarı, tutum ve bilimsel süreç becerileri üzerinde olumlu etkilerinin olduğu sonucuna varılmıştır (Karatekin, 2012). "TahminGözlem-Açıklama” tekniği ile dersler yürütüldüğünde, Genel Kimya dersine karşı öğrencilerin olumlu tutum geliştirdiği belirlenmiştir (Yavuz ve Çelik, 2013). TGA stratejisi ile zenginleştirilmiş animasyon destekli öğretimin öğrencilerin bilimsel başarıları, derse yönelik pozitif yönde tutumlar geliştirdikleri, derse yönelik ilginin arttığı ve bilgilerin kalıcıllğı tespit edilmiştir (Göktürk, 2015). Tahmin Et-Gözle-Açıkla yöntemiyle elektrik konusunun öğretiminin öğrencilerin bilimsel başarılarına anlamlı katkı sağladığı, fen bilgisi dersine karşı tutumlarını olumlu yönde etkilediği (Kırılmazkaya ve Zengin, 2015), tahmin et-gözle-açıkla yöntemiyle tasarlanan öğrenme ortamlarının 10. sınıf lise öğrencilerinin elektrik ve manyetizma konusu ve kavramlarını anlamada etkili olduğu ayrıca fizik dersine karşı motivasyonların da istatistiksel olarak anlamlı yönde artış gösterdiği tespit edilmiştir (Akkılık, 2016).

Öğrenciler TGA ile desteklenmiș etkinlikleri yaparken hatalı öğrenmelerini düzeltme fırsatı bulduklarını, böyle etkinliklerden hoşlandıkları ve zevk aldıkları, fen dersine olan ilgilerini artırdığını belirtmişlerdir (Yıldırım ve Maşeroğlu, 2016). Elde edilen bir diğer sonuca göre TGA yöntemi öğrenmede ve derse yönelik olumlu tutum oluşturmada pozitif katkı sağlamaktadır (Akarsu, 2018). TGA tekniğine dayalı olarak yapılan ders anlatımıyla ögrencilerinin daha fazla hevesli ve istekli oldukları, derse daha fazla katıldıkları ve daha kalıcı bir öğrenme gerçekleştirdikleri tespit edilmiştir (Baladın Duman, 2019). TGA yöntemi öğrencilerin akademik başarısını artırmıştır ayrıca öğrenciler bu etkinliklere karşı pozitif düşünceler içerisindedirler, öğretmen izlenimlerine göre de öğrencilerin tutumlarına olumlu etkisinin olduğu fark edilmiştir (Çetinkaya ve Hatay Uçar, 2020).

Öğrencilerin kimya dersine yönelik tutumlarının anlamlı bir şekilde artışı TGA yöntemine uygun etkinliklerin öğrencilerin başarı düzeylerini belirleme ve bilim anlayışlarına katkı sağlaması ile (Liew ve Treagust, 1998), TGA etkinliğinin suyun genleşmesi, tuzun çözünmesi ve elektrik konularında lise öğrencilerinin bir yandan başarılarının artmasını sağlarken diğer yandan, bilimsel beceri ve yeteneklerine önemli seviyede etki etmesi ile (Liew, 2004), TGA 
etkinliği kullanımının öğrencilerin kimyasal reaksiyonlarla ilgili bilgilerinin değişmesinde olumlu etki yaratması ve öğrencilerin TGA'ya karşı merak ve eğilimlerinin çoğalması ile (Keeratichamroen, Panijpan ve Dahsah, 2007), TGA stratejisinin öğrencilerin kavram yanılgılarının azalmasında etkili olması ile (Lestari, Prabowo ve Widodo, 2018) açıklanabilir.

Ayrıca TGA'nın diğer avantajlarının da öğrencilerin tutumlarını geliştirmelerini sağladığı düşünülmektedir. Örneğin TGA yardımcı materyalleri öğrencilerin öğrenme alışkanlıklarını iyileştirmek ve öğrenme kalitesini yükseltmek için elverişli bir öğrenme ortamı oluşturmaktadır (Rini, Suryani ve Fadhilah, 2019). TGA'nın kullanımı ile öğrencilerin kavramsal anlamaları artmış, eleştirel düşünme becerileri gelişmektedir. Bunun sonucu olarak TGA öğrencilerin bilgiyi uygulamaları için iyi bir yöntemdir (Furqani, Feranie ve Winarno, 2018). TGA uygulaması termodinamik konusunda öğrencilerin yanlış kavramlarını doğruya dönüştürmelerini sağlamıştır, bu aşamada öğrenciler hatalarından ders çıkarmışlardır (Zakiyah, Widodo ve Tukiran, 2019). TGA yöntemi bireylerin bilimsel olarak açıklayamadığ süreç içerisinde bilimsel olarak açıklayabilmelerini sağlamıştır (Köklükaya ve Güven Yıldırım, 2018). Fizik başarısının artırılmasında TGA'nın etkili bir yöntem olduğu belirlenmiştir. TGA'nın bu başarısı öğrencilerin ihtiyaçlarına, ilgi alanlarına uygun, sorgulayarak öğrenme sunması ve öğrenci merkezli bir yöntem olması ile açıklamaktadır (Venida ve Sigua, 2020). TGA yöntemine göre düzenlenmiş bir çalışma yaprağında öğrenciler önce bir tahminde bulunurlar, sonra bu tahmin ettikleri bilgiyi gözlemlerler ve açıklarlar. Gözlemlerle ilgili açıklamada ilerleme kaydettikleri ve tahmin işleminin ardından gözlem yapmanın konu ile ilgili yanlış anlamaları düzeltmede ve öğrenmeyi kalıcı hale getirmede etkili olduğun belirlenmiştir. Ayrıca TGA gibi öğretim yaklaşımının kullanılması durumunda öğrenenlerin bütün basamaklara aktif olarak katılım sağlayacağı da tespit edilmiştir (Güngör ve Özkan, 2020). Sonuç olarak kimya derslerinin TGA destekli çalışma yaprakları ile öğretimin öğrencilerin olumlu tutumlarını artırdığı, dersi artık daha güzel ve ilgi çekici buldukları, dersten sıkılmadıkları, tahmin ve açıkla aşamalarındaki gelişimlerini belirlemede olumlu katkılar sağladığı açıktır.

\section{ÖNERILER}

Araştırma bulgularına göre, bu alanda benzer çalışmalar yürütecek araştırmacı ve eğitimcilere ve aşağıdaki öneriler verilebilir.

- TGA tekniğine dayalı materyaller, 10. sinıf kimya dersi Endüstri ve Canlılarda Enerji Ünitesinin Hidrokarbonlar konusunda uygulanmıştır, diğer ünite konularında da uygulanabilir.

- TGA destekli materyaller sadece 10. Sınıf öğrencileri sınırlandırılmamalı, diğer sınıf düzeyinde bulunan öğrencileri ile de yapılabilir.

- TGA destekli materyallerin kullanımı sadece lise öğrenimi alan gruplarla sinırlandırılmamalı, ortaokul öğrencileri ve fen bilimleri öğretmen adayları ile de çalışmalar yapılmalı ve sonuçlar karşılaştırılmalıdır.

- Kimya dersine yönelik tutum dışında farklı veri toplama araçları kullanılabilir ve alana katkı sağlayacak sonuçlar paylaşılabilir.

- TGA destekli öğrenme etkinliklerinin Anadolu liseleri dışında meslek liseleri, fen liselerinde de uygulanabilirliği incelenebilir. 


\section{KAYNAKÇA}

Abbott, M.L. (2011). Understanding educational statistics using Microsoft Excel and SPSS. United States: John Wiley \& Sons, Inc.

Akarsu, A.H. (2018). Sosyal bilgiler öğretiminde tahmin et gözle açıkla (TGA) uygulamaları (Yayımlanmamış yüksek lisans tezi). Recep Tayyip Erdoğan Üniversitesi Sosyal Bilimler Enstitüsü, Rize.

Akkaya, R. (2010). Olasılık ve istatistik öğrenme alanındaki kavramlar gerçekçi matematik eğitimi ve yapılandırmacılık kuramına göre bilgi oluşturma incelenmesi (Doktora tezi). Uludağ Üniversitesi Sosyal Bilimler Enstitüsü, Bursa.

Akk1l1k, E. (2016). The predict-observe-explain instruction coupled with reflective journal writing for teaching electricity and magnetism: A quasi-experimantal study with grade 10 students (Yayımlanmamış yüksek lisans tezi). Boğaziçi Üniversitesi Fen Bilimleri Enstitüsü, İstanbul.

Altınok, O. (2017). TGA tekniğine dayalı laboratuvar etkinliklerinin fen bilgisi ögrretmen adaylarının argüman oluşturma becerilerine etkisinin incelenmesi. (Yüksek lisans tezi). Recep Tayyip Erdoğan Üniversitesi Fen Bilimleri Enstitüsü, Rize.

Altundağ Koçak, C. (2018). Context-based chemistry teaching within the 4Ex2 model: Its impacts on metacognition, multiple intelligence, and achievement. Journal of Turkish Science Education, 15(2), 1-12.

Aydoğdu, C. (1999). Kimya Laboratuvar uygulamalarında karşılaşılan güçlüklerin saptanması. Hacettepe Üniversitesi Ĕ̈itim Fakültesi Dergisi, 15, 30-35.

Baladın Duman, B. (2019). Besin içerikleri ve sindirim sistemi konularında TGA yöntemine dayalı olarak geliştirilen etkinliklerin değerlendirilmesi. (Yayımlanmamış yüksek lisans tezi). Trabzon Üniversitesi Lisansüstü Eğitim Enstitüsü, Trabzon.

Bednar, A.K., Cunningham, D., Duffy, T.M. ve Perry, J.D. (1992). Theory into practice: How do we link. Constructivism and the Technology of Instruction: A Conversation, 17-34.

Bilen, K. (2009). Tahmin Et-Gözle-Açıkla” (TGA) stratejisine dayalı laboratuvar yaklaşımı ile hazırlanan etkinliklerin, fen bilgisi ögretmen adaylarının kavramsal başarılarına, bilimsel süreç becerilerinin gelişimine, biyoloji laboratuvarına yönelik tutumlarına ve bilimin doğasını hakkındaki görüşlerine etkisi. Yayınlanmamış doktora tezi, Gazi Üniversitesi Eğitim Bilimleri Enstitüsü, Ankara.

Broman, K., Ekborg, M. ve Johnels, D. (2011). Chemistry in crisis? Perspectives on teaching and learning chemistry in Swedish upper secondary schools. Nordic Studies in Science Education, 7(1), 43-60.

Cheung, D. (2008). Facilitating chemistry teachers to implement inquiry-based laboratory work. International Journal of Science and Mathematics Education, 6(1), 107-130.

Cheung, D. (2011). Teacher beliefs about implementing guided-inquiry laboratory experiments for secondary school chemistry. Journal of Chemical Education, 88(11), 1462-1468.

Chew, C. (2008). Effects of biology infused demonstrations on achievement and attitudes in junior college. Unpublished Ph.D Thesis. The University of Western Australian Education of Faculty.

Çetinkaya, S. ve Hatay Uçar, F. (2020). Current researches in educational sciences. In Şahin, H. ve İnan, R. (Ed). The effect of using multimedia-supported predict-observe-explain technique in 2nd grade life science on students' achievement and their ability to relate to daily life. (p.229-244). Montenegro: Ivpe Cetinje Press. 
Fitriani, A., Zubaidah, S., Susilo, H. ve Al Muhdhar, M. H. I. (2019). The integrated problem based learning and predict, observe, explain (pbl-poe) to empower students' problemsolving skills. Proceedings of the 3rd International Conference on Education and Multimedia Technology, p. 375-379.

Furqani, D., Feranie, S. ve Winarno, N. (2018). The effect of predict-observe-explain (POE) strategy on students' conceptual mastery and critical thinking in learning vibration and wave. Journal of Science Learning, 2(1), 1-8.

Göktürk, M. (2015). Fen ve teknoloji dersinde TGA stratejisi ile zenginleştirilmiş animasyon destekli öğretimin akademik başarıya, tutuma ve kalıcılı̆̆a etkisinin incelenmesi. Yayımlanmamış Yüksek Lisans Tezi. Ağrı İbrahim Çeçen Üniversitesi Fen Bilimleri Enstitüsü, Ağrı.

Güngör, S.N. ve Özkan, M. (2020). Teaching the relationship between metabolic rate and $\mathrm{O}_{2}$ consumption of animals with fixed/variable body temperature by use of the predictobserve-explain (POE) strategy. Pamukkale Üniversitesi Eğitim Fakültesi Dergisi, doi: 10.9779/pauefd.473054. Onlinefirst, 1-22.

Güven, E. (2011). Çevre eğitiminde tahmin-gözlem-açılama destekli proje tabanlı ögrenme yönteminin farkl değişkenler üzerine etkisi ve yönteme ilişkin ögrenci görüşleri. Yayımlanmamış Doktora Tezi. Gazi Üniversitesi Eğitim Bilimleri Enstitüsü, Ankara.

Hong J.C., Hwang M.Y., Liu M.C., Ho H.Y. ve Chen Y.L. (2014). Using a "predictionobservation-explanation" inquiry model to enhance student interest and intention to continue science learning predicted by their Internet cognitive failure. Computers \& Education, 72, 110-120.

Kan, A. ve Akbaş, A. (2005). Lise öğrencilerinin kimya dersine yönelik tutum ölçeği geliştirme çalışması. Mersin Üniversitesi Eğitim Fakültesi Dergisi, 1(2), 227-237.

Karadeniz, A., Koçak Altundağ, C. ve Yücel, A.S. (2020). Tahmin et-gözle-açıkla yöntemi destekli etkinliklerin lise öğrencilerinin üst biliş farkındalıklarına etkisinin araştırılması. Abant İzzet Baysal Üniversitesi Ĕ̈itim Fakültesi Dergisi, 20(4), 1881-1898.

Karasar, N. (2003). Bilimsel araştırma yöntemi. (12. baskı). Ankara: Nobel Yayınları.

Karatekin, P. (2012). Fen ve Teknoloji öğretmen adaylarının biyoloji laboratuarlarında tekniğinin ögrencilerin başart, tutum ve bilimsel süreç becerileri üzerine etkisi. Yayımlanmamış Yüksek Lisans Tezi. Celal Bayar Üniversitesi Fen Bilimleri Enstitüsü, Manisa.

Keeratichamroen, W., Panijpan, B. ve Dahsah, C. (2007). Using the predict-observe- explain (poe) to promote students' learning of tapioca bomb and chemical reactions. Mahidol University Annual Research Abstracts, 35, 563.

Kırılmazkaya, G. ve Zengin-Kırbağ, F. (2015). Tahmin et-gözle-açıkla yönteminin ortaokul öğrencilerinin akademik başarılarına ve fene karşı tutumlarına etkisinin incelenmesi. Uluslararası Sosyal Araştırmalar Dergisi, 8(41), 975-981.

Kirk, R.E. (2008). Statistics an introduction (Fifth edition). United States: Thomson Higher Education.

Köklükaya, A.N. ve Güven Yıldırım, E. (2018). Science teacher candidates' expression levels on the expansion of water subject by prediction-observation-explanation method. Journal of Multidisciplinary Studies in Education, 2(1), 16-27.

Lestari, L. D., Prabowo, P. ve Widodo, W. (2018). Reducing light misconceptions by using predict-observe-explain strategies. Advances in Intelligent Systems Research, 157, 64-67. 
Liew, C. W. (2004). The effectiveness of predict-observe-explain technique in diagnosing students' understanding of science and identifying their level of achievement. (Unpublished PhD. Thesis). Curtin University of Technology, Science and Mathematics Education Centre.

Liew, C.W. ve Treagust, D.F. (1998). The effectiveness of predict-observe-explain tasks in diagnosing students' understanding of science an identifying their levels of achievement. Paper Presented at the Annual Meeting of American Educational Research Association, San Diego, CA.

McGregor, L. ve Hargrave, C. (2008). The use of predict-observe-explain with on-line discussion boards to promote conceptual change in the science laboratory learning environment. Proceedings of SITE 2008--Society for Information Technology \& Teacher Education International Conference, 4735-4740.

McKillup, S. (2012). Statistics explained: An introductory guide for life scientists (Second edition). United States: Cambridge University Press.

Muhibbuddin, M., Ilyas, S. ve Para Samya, C.E. (2019). Improving critical thinking skill and scientific behavior through the implementation of predict observe explain learning model. International E-Journal of Advances in Education, 5(15), 337-342.

Mujtaba, T., Sheldrake, R. ve Reiss, M. J. (2020). Chemistry for all. Reducing inequalities in chemistry aspirations and attitudes. England: Royal Society of Chemistry.

Osborne, R.J. ve Wittrock, M.C. (1983). Learning science: A generative process. Science Education, 67(4), 489-508.

Özdemir, Ö. (2006): İlköğretim 8. sınıf türün devamlılı̆̆ını sağlayan canlılık olayı (üreme) konusunun çalı̧̧ma yaprakları ile öğretiminin öğrenci erişisine ve kalıcılı̆̆a etkisi (Yayınlanmamış Yüksek Lisans Tezi) Dokuz Eylül Üniversitesi Eğitim Bilimleri Enstitüsü, İzmir.

Özden, M. (2007). Kimya öğretmenlerinin kimya öğretiminde karşılaştıkları sorunların nitel ve nicel yönden değerlendirilmesi: Adıyaman ve Malatya illeri örneği. Pamukkale Üniversitesi Ĕ̈itim Fakültesi Dergisi, 22, 40-53.

Özmen, H. (2004). Fen öğretiminde öğrenme teorileri ve teknoloji destekli yapılandırmaci (constructivist) öğrenme. The Turkish Online Journal of Technology, 3(1), 100-111.

Pallant, J. (2005). SPSS Survival guide: A step by step guide to data analysis using SPSS for windows. 3rd Edition, New York: Open University Press.

Palmer, D.H. (1999). Exploring the link between students' scientific and nonscientific conceptions. Science Education, 83, 639-653.

Ramnarain, U. (2016). Understanding the influence of intrinsic and extrinsic factors on inquirybased science education at township schools in South Africa. Journal of Research in Science Teaching, 53(4), 598-619.

Rini, A.P., Suryani, N. ve Fadhilah, S. S. (2019). Development of the predict observe explain (POE)-based thematic teaching materials. International Journal of Educational Research Review, 4(1), 1-7.

Rusçuklu, P. ve Özdilek, Z. (2019). Bütünleştirilmiş anlaşma halkaları ve TGA yönteminin çözünürlüğe etki eden faktörler konusundaki kavramsal anlamaya etkisi. Eskişehir Osmangazi Üniversitesi Sosyal Bilimler Dergisi, 20, 621-648.

Rüschenpöhler, L. ve Markic, S. (2020). Secondary school students' acquisition of science capital in the field of chemistry. Chemistry Education Research and Practice, 21(1), 220-236. 
Samsudin, A., Suhandi, A., Rusdiana, D., Kaniawati, I. ve Coştu, B. (2016). Investigating the effectiveness of an active learning based-interactive conceptual instruction (ALBICI) on electric field concept. In Asia-Pacific Forum on Science Learning and Teaching, 17(1), 141.

Sharma, S. (1996). Applied multivariate techniques. United States: John Wiley \& Sons. Inc.

Sheldrake, R. ve Mujtaba, T. (2020). Children's aspirations towards science-related careers. Canadian Journal of Science, Mathematics and Technology Education, 20, 1-20.

Sreerekha, S., Raj, A.R. ve Sankar, S. (2016). Effect of predict-observe-explain strategy on achievement in chemistry of secondary school students. International Journal of Education \& Teaching Analytics, 1(1), 1-5.

Tabachnick, B.G. ve Fidell, L.S. (2013). Using multivariate statistics (Sixth edition). United States: Pearson Education.

Tan, E. (2008). Illköğretim 7. sınıf dil bilgisi ögretiminde zarflar konusuyla ilgili yapılandırmacı yaklaşıma göre hazırlanmış çalışma yapraklarının öğrenci başarısına etkisi (Yayınlanmamış Yüksek Lisans Tezi). Atatürk Üniversitesi Sosyal Bilimler Enstitüsü, Erzurum.

Thode, H.C. (2002). Testing for normality. United States: Marcel Dekker, Inc.

Tekin, S. (2008). Tahmin-gözlem-açıklama stratejisinin fen laboratuvarında kullanımı: Kükürdün molekül kütlesi nedir? Erzincan Eğitim Fakültesi Dergisi, 10(2), 173-184.

Venida, A.C. ve Sigua, E. M. (2020). Predict-observe-explain strategy: effects on students' achievement and attitude towards physics. Jurnal Pendidikan MIPA, 21(1), 78-94.

von Glasersfeld, E. (1995). A constructivist approach to teaching. In L. P. Steffe and J. Gale (Eds.), Constructivism in Education (pp.3-15). New Jersey: Lawrence Erlbaum Associates.

White, R. ve Gunstone, R.F. (1992). Prediction-observation-explanation. In R. White and R. F. Gunstone (Eds.), Probing Understand (pp.44-64). London, UK: The Falmer Press.

Yaman, F. ve Ayas, A. (2015). Assessing changes in high school students' conceptual understanding through concept maps before and after the computer-based predictobserve-explain (CB-POE) tasks on acid-base chemistry at the secondary level. Chemistry Education Research and Practice, 16, 843-855.

Yavuz, S. ve Çelik, G. (2013). Sınıf öğretmenliği öğrencilerinin gazlar konusundaki kavram yanılgılarına tahmin-gözlem-açıklama tekniğinin etkisi. Karaelmas Eğitim Bilimleri Dergisi, 1(1), 1-20.

Yıldırım, N. ve Maşeroğlu, P. (2016). Kimyayı günlük hayatla ilişkilendirmede tahmin-gözlemaçılamaya dayalı etkinlikler ve öğrenci görüşleri. Turkish Online Journal of Qualitative Inquiry, 7(1), 117-145.

Zakiyah, I., Widodo, W. ve Tukiran, T. (2019). The effectiveness of predict-observe-explain strategy to reduce misconception in thermochemistry. Advances in Computer Science Research, 95, 139-142.

\section{EXTENDED ABSTRACT}

These days, what needs to be done to obtain an innovative education system is a pioneer of a major change. Models, approaches and methods implemented in developed countries are taken as role models in many developing countries and similar practices are tried to be used. It has been 
proven by many studies that traditional educational practices of the past do not produce a sufficient and permanent effect on the learning status of today's individuals (von Glasersfeld, 1995; Tan, 2008). Reasons such as the chemistry curriculum being very intense and insufficient time allocated to chemistry course content in education programs, the lack of teachers in schools, the course load on the teacher, etc. cause to not have much time to do an experiment in the class. In the chemistry teaching process, instructional strategies, techniques, methods and models containing the basic principles of the constructivist approach should be used in order to identify the alternative concepts that students have, correct them and develop a more effective teaching approach. One of the teaching methods that is based on the constructivist learning approach and can be applied by teachers without difficulty is the "Prediction-Observation-Explanation" (POE) method (White, \& Gunstone, 1992). In the POE strategy, students are challenged by comparing them with experimental situations and asking for a prediction about the results, and then observation about the situation is expected. After that, explanation is provided comparing their predictions with their observations.

The purpose of this research is to investigate the effects of teaching of the chemistry taught using materials supported by the POE (predict-observe-explain) on students' attitudes towards chemistry course. In the research, quasi-experimental design with pretest-posttest control group was used. The sample group of the research consists of approximately 100 students studying in 4 different 10th grades in two different Anatolian High Schools in Ankara in the 20162017 academic year. The research was carried out with a total of 100 students, 50 in the experimental group and 50 in the control group. The study group of the research was determined by the convenience sampling method. As the lessons were carried out with POE supported materials in the experimental groups; however, traditional method was carried out in the control groups. In the research, attitude towards chemistry course scale was used as the data collection tool. Scale was developed by Kan and Akbaş (2005), and consisted of 22 statements in a 5-point Likert Type. Scale have three dimensions. These dimensions are negative emotion towards chemistry lesson, positive emotion towards chemistry lesson and activity for chemistry lesson. Cronbach alpha reliability co-efficient for the whole scale is 0.92 , and for sub-dimensions in turn $0.87,0.87$ and 0.78 .

Descriptive statistics were made primarily in the analysis of the data. The average of high school students' attitudes towards chemistry course was determined. Experimental and control groups' attitudes towards chemistry lesson before application were determined and whether there was a difference between them was compared. Posttest scores obtained from sub-dimensions of attitude scale towards chemistry course were analyzed with Multivariate Analysis of Variance (MANOVA).

In the research, firstly, it was checked whether there was a significant difference between the attitude sub-dimensions of the students in the experimental and control groups towards the attitudes towards chemistry course pretest scores. It was determined that there was a significant difference among the attitudes towards chemistry course pre-test scores of high school students. This would affect the analysis among the posttest scores. Therefore, an analysis method was applied to eliminate this effect among pre-tests. According to the analysis result, there was a statistically significant difference between experiment and control groups in all sub-dimensions of the scale posttest scores. The averages of experiment 1 and 2 groups in all sub-dimensions of the scale are higher than the control 1 and 2 groups, and the difference between the averages is statistically significant. POE supported materials have been effective in increasing students' attitudes towards chemistry. When the literature is examined, the finding of the positive effect of POE on attitude is similar to other studies (McGregor, \& Hargrave, 2008; Hong, Hwang, Liu, Ho, \& Chen 2014; Sreerekha, Raj, \& Sankar 2016; Rusçuklu, \& Özdilek, 2019; Venida, \& Sigua, 2020). Students state that they have the opportunity to correct their false learning while doing activities supported by POE, and they like and enjoy such activities and increase their interest in science courses (Yıldırım, \& Maşeroğlu, 2016). According to another result obtained, the POE 
method has been considered to contribute positively to learning information and developing positive attitudes towards the course (Akarsu, 2018). It has been determined that the students are more enthusiastic and willing, participate in the class more and experience a more permanent learning with the lectures based on POE technique (Baladın Duman, 2019). The POE method has increased the academic success of students. In addition, students have positive thoughts about these activities, and it has been noticed that they have a positive effect on the attitudes of students according to teacher impressions as well (Çetinkaya, \& Hatay Uçar, 2020). 